\section{NTS 2020/45}

HR 28 januari 2020, 18/02966, ECLI:NL:HR: 2020:79

Beoordeling van een aanhoudingsverzoek in een situatie die hierdoor mordt gekenmerkt dat raadsman op de $t z$. aangeeft dat hij niet meet waarom verdachte niet is verschenen en dat hij het mogelijk acht dat verdachte geen weet heeft van de zitting en om die reden een aanhoudingsverzoek doet

\section{Aantekening redactie}

De verdachte in deze zaak is door het hof wegens 'Opzettelijk handelen in strijd met een in artikel 2 onder B van de Opiumwet gegeven verbod', veroordeeld tot zes maanden gevangenisstraf. Het middel bevatte de klacht dat de afwijzing door het hof van het verzoek om aanhouding in verband met de afwezigheid van verdachte getuigt van een onjuiste rechtsopvatting, althans dat de afwijzing onvoldoende met redenen is omkleed, terwijl het hof er geen blijk van heeft gegeven de vereiste belangenafweging te hebben gemaakt.

Het proces-verbaal van de zitting van 20 februari 2018 houdt dienaangaande het volgende in:

'De verdachte, opgeroepen als:

[verdachte],

geboren te [geboorteplaats] op [geboortedatum] 1972, adres: [b-straat 1] te [postcode] [plaats],

is niet ter terechtzitting verschenen.

(...)

Desgevraagd door de voorzitter deelt de raadsman het volgende mede:

Ik heb mijn cliënt niet kunnen bereiken en weet dus niet of mijn cliënt op de hoogte is van de zitting van heden.

De voorzitter deelt mede dat de oproeping om ter terechtzitting van heden te verschijnen op de juiste wijze aan de verdachte is betekend.

De raadsman deelt hierop mede:

Ik verzoek $u$ de onderhavige zaak an te houden nu mijn cliënt niet is verschenen. Ik begrijp namelijk niet waarom hij er niet is. Mijn cliënt is ter terechtzitting in eerste aanleg namelijk wel verschenen en ook bij de eerste zitting van dit hof op 17 februari 2016 was hij aanwezig. Het telefoonnummer dat ik van hem heb, is niet meer in gebruik.

Desgevraagd door de oudste raadsheer deelt de raadsman mede:

Ik heb geen goede onderbouwing en ik kan het verzoek tot aanhouding niet beter onderbouwen. Het heeft mijn voorkeur de zaak te behandelen in aanwezigheid van mijn cliënt.

De advocaat-generaal verzet zich - gelet op het tijdsverloop, het geen nieuwe stukken toegevoegd zijn aan het dossier en de omstandigheid dat verdachte geen contact met raadsman heeft gezocht - tegen aanhouding van de zaak.

De voorzitter onderbreekt vervolgens het onderzoek voor beraad.

Na beraad wordt het onderzoek hervat en deelt de voorzitter als beslissing van het hof mede dat het verzoek tot aanhouding van de zaak wordt afgemezen. De voorzitter deelt hierop mede dat het verzoek tot aanhouding van de raadsman niet deugdelijk is onderboumd en dat er sinds de laatste zitting van het hof op 17 februari 2016 - op melke zitting de verdachte en diens raadsman beiden aanmezig maren - geen (inhoudelijk) nieume stukken aan het dossier zijn toegevoegd, die een ander en/of nieum licht merpen op hetgeen aan de verdachte is ten laste gelegd.

Desgevraagd door de voorzitter deelt de raadsman mede door de verdachte uitdrukkelijk gemachtigd te zijn de verdediging te voeren.

Met instemming van de advocaat-generaal en de raadsman van de verdachte hervat het hof - ondanks zijn gewijzigde samenstelling - het onderzoek in de stand waarin het zich op het tijdstip van de schorsing op 2 maart 2016 bevond.'

In de onderhavige zaak rijst de vraag hoe een verzoek tot aanhouding moet worden beoordeeld in een situatie die, kort gezegd, hierdoor wordt gekenmerkt dat de raadsman op de terechtzitting aangeeft dat hij niet weet waarom de verdachte niet is verschenen en dat hij het mogelijk acht dat de verdachte geen weet heeft van de zitting, en om die reden een aanhoudingsverzoek doet. Voor de beoordeling door de rechter van een aanhoudingsverzoek in zo'n geval is in het algemeen het volgende van belang. ${ }^{34}$ De aan het verzoek tot aanhouding ten grondslag gelegde omstandigheid dat de verdachte (mogelijk) geen weet heeft van de zitting, kan zonder meer als 'niet aannemelijk' worden beoordeeld indien de dagvaarding of oproeping voor de terechtzitting in persoon is betekend. Dan kan de rechter het verzoek reeds op deze grond afwijzen. Indien de dagvaarding of de oproeping weliswaar niet in persoon is uitgereikt, maar wel op

34. Zie HR 6 oktober 2018, ECLI:NL:HR:2018:1934 (overzichtsarrest aanhoudingsverzoeken) i.c.m. HR 9 juli 2019, ECLI:NL:HR:2019:1142. 
rechtsgeldige wijze - dat wil zeggen: in overeenstemming met de ter zake geldende wettelijke voorschriften (art. 585-590 Sv) alsmede de in de rechtspraak van de Hoge Raad tot uitdrukking gebrachte regels - is betekend, kan de rechter dat verzoek niet op die enkele grond afwijzen. Uit zo'n betekening volgt immers niet zonder meer dat de verdachte op de hoogte is van de zitting. In dat geval is een afwijzing van het verzoek tot aanhouding op de grond dat de aan dat verzoek ten grondslag gelegde omstandigheid niet aannemelijk is, alleen mogelijk indien op basis van andere omstandigheden kan worden vastgesteld dat de verdachte daadwerkelijk weet heeft van de zitting. Indien niet kan worden vastgesteld dat de verdachte daadwerkelijk weet heeft van de zitting, dient de rechter een afweging te maken tussen alle bij aanhouding van het onderzoek ter terechtzitting betrokken belangen. Bij die belangenafweging kan vervolgens wel betekenis toekomen aan de omstandigheid dat de dagvaarding of de oproeping voor de terechtzitting in hoger beroep op rechtsgeldige wijze, zij het niet in persoon, is betekend. Zoals tot uitdrukking is gebracht in HR 12 maart 2002, ECLI:NL:HR:2002:AD5163, r.o. 3.36-3.37, mag dan immers van de verdachte die hoger beroep instelt en prijs stelt op berechting op tegenspraak, worden verwacht dat hij de in het maatschappelijke verkeer gebruikelijke maatregelen neemt om te voorkomen dat de appeldagvaarding hem niet bereikt of de inhoud daarvan hem niet bekend wordt. Tot die maatregelen kan in elk geval worden gerekend dat de verdachte zich bereikbaar houdt voor zijn raadsman - die uit eigen hoofde een afschrift van de appeldagvaarding ontvangt indien hij zich in hoger beroep heeft gesteld - opdat de verdachte in voorkomende gevallen (ook) langs die weg van het tijdstip van behandeling van zijn zaak op de hoogte komt. Het kennelijk niet treffen door de verdachte van dergelijke in het maatschappelijke verkeer gebruikelijke maatregelen kan de rechter in hoger beroep - naast andere factoren die daarvoor van belang kunnen zijn, zoals het procesverloop en het gewicht van de zaak - in de vereiste belangenafweging betrekken.

In de onderhavige zaak heeft het hof met de overweging dat het verzoek door de raadsman 'niet deugdelijk' is onderbouwd, kennelijk als zijn oordeel tot uitdrukking gebracht dat de aan het verzoek tot aanhouding van het onderzoek ter terechtzitting ten grondslag gelegde omstandigheid dat de verdachte mogelijk geen weet heeft van de zitting, niet aannemelijk is. Dat oordeel was volgens de Hoge Raad niet begrijpelijk, in aanmerking genomen dat blijkens het verhandelde ter terechtzitting de oproeping in hoger beroep niet aan de verdachte in persoon is uitgereikt, terwijl het hof niet heeft vastgesteld dat de verdachte anderszins op de hoogte is geraakt van de datum van de zitting. Het hof had, bij die stand van zaken, dus de hiervoor weergegeven afweging moeten maken tussen alle bij aanhouding van het onderzoek ter terechtzitting betrokken belangen. Het hof heeft er echter geen blijk van gegeven die afweging te hebben gemaakt. De enkele omstandigheid dat volgens het hof in de periode tussen de zitting van 17 februari 2016 en die van 20 februari 2018 'geen (inhoudelijke) nieuwe stukken aan het dossier zijn toegevoegd, die een ander en/of nieuw licht werpen op hetgeen aan de verdachte is ten laste gelegd' kan een dergelijke afweging niet vervangen. Het middel slaagde dan ook.

\section{NTS 2020/46}

\section{HR 28 januari 2020, 19/00182, ECLI:NL:HR:} 2020:121

\begin{abstract}
OM-cassatie. Vrijspraak van opzettelijk onjuist/onvolledig doen van aangifte omzetbelasting en inkomstenbelasting op naam van medeverdachte en/of haar eenmanszaak (art. 69 AWR). Is het opzettelijk onjuist of onvolledig doen van een bij de belastingmet voorziene aangifte een kmaliteitsdelict zodat alleen een aangifteplichtige als pleger kan morden aangemerkt?
\end{abstract}

\section{Aantekening redactie}

De verdachte is door het hof vrijgesproken van het onder 1 en 2 tenlastegelegde en wegens ' 3 . medeplegen van het feit begaan, omschreven in artikel 68, eerste lid, onderdeel c, van de Algemene wet inzake rijksbelastingen, terwijl het feit ertoe strekt dat te weinig belasting wordt geheven, meermalen gepleegd' veroordeeld tot een taakstraf voor de duur van 40 uren subsidiair 20 dagen hechtenis. Het middel van het openbaar ministerie klaagde dat het oordeel van het hof dat de verdachte niet als pleger van het hem onder 1 en 2 tenlastegelegde kan worden aangemerkt blijk gaf van een onjuiste rechtsopvatting, althans onbegrijpelijk was.

In deze zaak ging het om de heffing van belasting op de omzet van en de inkomsten uit een winkel. De winkel (A) is een eenmanszaak en wordt gevoerd op naam en voor rekening van de vrouw van verdachte. Verdachte doet (in de hier relevante periode) de administratie en verzorgt de belastingaangiften. De verdachte heeft verklaard dat de administratie niet op orde was en dat daardoor de aangiften ook niet klopten. Het middel bestrijdt de motivering van de vrijspraak voor de feiten 1 en 2 voor zover deze inhoudt dat verdachte 'zelf niet verplicht was tot het doen van de in de tenlastelegging genoemde aangiften'. Het hof heeft de verdachte van deze feiten vrijgesproken en daartoe het volgende overwogen:

'Onder de feiten 1 en 2 wordt de verdachte - kort gezegd - verweten dat hij zich samen met de medeverdachte, althans alleen, heeft schuldig gemaakt aan 